већ круже одељењем и да „се прича“ да је књига супер. Дакле, иако је примарна мотивација ученика била жеља да учествују у нечему важном и/ли да помогну својој професорици, а не чиста и непомућена читалачка радозналост и читалачка страст, књигу је прочитало 19 ученика (од 24 у одељењу).

Уочи одржавања научног скупа, питала сам их да ми дају видео интервјуе. Сложили су се да изложе своје утиске, да прокоментаришу шта је, према њиховом мишљењу, кључни проблем у роману итд. Учинили су то са задовољством. Чак су и сами монтирали снимак, додајући малу бравурицу на крају! Била сам веома поносна на њих и са задовољством сам приказала њихов видео-рад на округлом столу Читате ли Јелену Димитријевић? 9. априла 2016. године. Жао ми је што ученици нису могли да чују аплауз и приме похвале.

Видео-рад Ми читамо Јелену Димитријевић пружа драгоцене смернице методичарима и практичарима. Он је потврда да ученике ваља укључивати у процес избора књижевних текстова у школским програмима. Такође, он је прилог гинокритичком преиспитивању педагошког канона, упућујући на потребу његовог кориговања - укључивања романа Нове, на пример. Видео-рад je, напослетку, резултат ентузијазма, истрајности, радозналости, полемика, сарадње, разумевања, маштања, неслагања, читалачке љубави - верујем да ово може да осети свако ко га погледа. А све то је подстакла једна књига - Нове Јелене Димитријевић. Чини ми се да је и више него довољно разлога да се сви средњошколци упознају са њом.

Сто година након првог издања, у Гласниковој едицији Сопствена соба, посвећеној књижевном стваралаштву домаћих и страних ауторки, објављено је ново издање романа Нове Јелене Димитријевић. Након поновног објављивања Писама из Ниша: о харемима (Народна библиотека Србије - Дечије новине, 1986; Просвета, 2003) и Писама из Солуна (Карпос, 2008), ново издање својевремено знаменитог романа Јелене Димитријевић представљало је трећи корак ка поновном уласку једне од најзначајнијих српских ауторки на домаћу издавачку и читалачку сцену. Четири године након Гласниковог издања Нових, може се говорити о новој генерацији читалаца дела Јелене Димитријевић. У форми писма, уредница Гласниковог издања Нових, ауторку романа извештава о њеном уласку у Гласникову Сопствену собу, о њеном поновном изласку пред ширу читалачку јавност, као и о томе ко, како и зашто данас чита њене Нове. Сачињено у духу својеврсне перформативне критике и теорије рецепције, писмо настоји да сумира значај који роман Нове има више од сто година након што је први пут објављен.

кључне речи: Јелена Димитријевић, Нове, писмо, читаоци, перформативна критика, теорија рецепције 

могло да измени ново издање Вашег својевремено знаменитог романа, независно од моје, посве личне, уредничке жеље да Вас уврстим у своју, тада недавно основану, едицију Сопствена соба. Признала сам Вам тада, а нема разлога да то и сада не поновим jep, надам се, моје речи нећете разумети као пригодно ласкање, већ као израз дубоког поштовања, да сте Ви једна од књижевница због којих је Сопствена соба и настала. Када сам је замишљала видела сам Вас, Милицу Јанковић, Вирџинију Вулф (Virginia Wolf) и Идит Вортон (Edith Wharton) - видела сам како Ваше име поносно краси библиотеку Сопствене собе и громогласно објављује да књижевност коју су писале жене у Србији стоји, раме уз раме, с књижевношћу које су стварале жене широм света. Судбина Вашег имена и Ваших дела након 1945. године подстакла ме је да, као и поједини пре мене, покушам да исправим неправду нанету Вама и

многим Вашим савременицама, као и да се надам да ће они који буду читали Вас и Вирџинију Вулф у Сопственој соби увидети до које мере су ваше књижевности исте вредности. Питала сам се тада, зашто Ви не словите за нашу Вирџинију Вулф? И хтела сам да учиним све у мојој моћи да Вам пружим прилику да то постанете. На срећу, нисам била усамљена у тим напорима - превелики је био талог заборава и немара да бих сама могла да га отресем. За то што је до данас наново објављено десетак Ваших дела и што је о њима написано на десетине научних радова објављених у периодици и зборницима, неколицина магистарских и докторских радова, ипак позамашан број новинских чланака и записа на интернет страницама, за тај дивљења вредан корпус писаних речи који Вас и Ваше дело, свакодневно, отржу од заборава, заслужни су многи. Писаћу Вам, биће прилике, надам се, некад и о томе. Сада бих да с Вама поделим, осећам то као своју уредничку и поштоватељску потребу, утиске о судбини Ваших Нових, четири године након што су оне, на моју велику радост, из Сопствене собе наново изашле у свет.

И данас се, несмањеним жаром, радујем када год видим наше издање Нових. Волим све у вези са њима! Сјајну опрему, крајње нескромно с моје стране, што ћете ми, надам се опростити, једну од најлепших које се данас могу видети у нашим књижарама. Брижљиво сачињен преглед Вашег живота и дела у којем је професорка Биљана Дојчиновић дочарала богатство Вашег узбудљивог живота и разноликост Вашег значајног опуса. Писала сам Вам онда пре четири године, али ми, надам се, нећете замерити што ћу понешто од тога поновити, колико сам волела да читам Ваш роман.

Требало ми је, с жаљењем признајем, превише времена да нађем свој пут до њега. Разлога за то је много, а правог оправдања заправо нема. Тешко да ћу икада преболети то што сам себе лишила задовољства да Нове изнова читам у различитим животним добима, као што сам чинила с многим другим књигама, и да осећам радост сваки пут када откријем и разумем нешто ново у том добро познатом тексту. Но, срећа у тој читалачкој несрећи, изазваној својеврсном лењошћу духа, јесте то што сам се с Новима сусрела 
као, чини ми се, довољно зрела читатељка. Волим да мислим да ми је то омогућило да им се вољно препустим, како је то срочио један од мојих омиљених проучавалаца књижевности, да их читам без сумње, уздржаности, преиспитивања, да невино верујем у свет романа који сте створили, да заједно с Вашим јунакињама осећам разапетост између, како стоји у поговору нашег издања, „старог и новог, традиционалног и модерног, Истока и Запада, стварности и фикције“, да учествујем у напорима Емир-Фатме да свој сан претвори у стварност и да с њом делим очај који доноси разочарање у тај постварени сан, да ватрено навијам за Арифине револуционарне покличе који младе Туркиње позивају на буђење из чаробног сна Истока и да се заједно с њом питам, једном кад револуција почне да једе своје кћери, да није ипак било прерано за буђење? Речју, када сам први пут читала Ваше Нове, ја сам их и живела! Ипак, нисам могла а да се повремено не пробудим из опојног сна Ваше књиге, да пренебрегнем сво Ваше приповедачко умеће! Ваш језик или боље рећи језици! Мало је рећи да сам се стидела сопственог сиромаштва познавања страних језика у поређењу с Вашим, и још мање да сам о матерњем језику од Вас научила много више но у свим оним часовима проведеним у свакојаким школским клупама. А тек Ваши смели и умешни приповедачки избори! Уплитање субјективног у објективно приповедање, вешто изведено мешање жанрова - не могу Вам описати срећу која ме је обузела што сте ми доказали да је модернизам врхунио и код нас, а не само у Енглеској! Но, као највеће богатство које ми је и невино и подозриво читање Вашег романа подарило морам издвојити, тако живописно приказану разлику између жене и жене!

Не могу се похвалити, у мери у којој сте Ви могли, да сам светска путница. Но, стицајем извесних животних околности, провела сам извесно време у исламском свету недуго након што сам уредила наше Нове. Ражалостиће Вас, уверена сам, да чујете да се није много тога променило од времена када сте Ви боравили у том свету. Тамо жена још увек није посве жена! Истина је да су неке од њих скинуле чаршафе и оставиле само велове којим скривају своје косе, да се оне и даље заогрнуте у црне покривке не либе да покажу да испод њих скривају нашминкана лица и раскошне хаљине, да се поједине међу њима школују на Западу и да имају каријере, али када су посреди избори њихових срца, правог избора заправо и даље нема. Током свог боравка међу муслиманским женама нисам имала прилике да као Ви задобијем њихово безусловно поверење да ми открију баш све појединости њихових приватних живота, као што су то Вама својевремено чиниле Туркиње у Нишу, али сам од једне од њих ипак понешто сазнала. Образована у Америци - могу само да замислим шта бисте Ви учинили од те животне ситуације - одгајана у породици универзитетских професора, слободна да путује, ради и, рекло би се, ужива у преимућствима савременог живота, она ипак не може и неће дозволити да њено срце припадне некоме ко у потпуности не дели њену веру, културу и вредности. За разлику од Емир-Фатме, она неће ни покушати да пркоси вољи својих родитеља. Волим да мислим да сам у њој препознала Емир-Фатмину унуку ону која је трезвено и обазриво прихватила погодности пробуђене свести, али која се исто тако никада не би дрзнула да оглушењем о традицију изазове трагичну судбину. Можете ме питати, као што сам се и сама питала, је ли она срећна у том својем, наоко, складном преплету старог и новог, традиционалног и модерног, Истока и Запада? Нажалост, не могу Вам са сигурношћу рећи. Премало сам времена провела са њом, недовољно да бих се уверила да ће се снаћи у свакој неочекиваној ситуацији коју јој живот може донети. Али оно што Вам засигурно могу потврдити јесте да се у њој, за разлику од Емир-Фатме, не може очитати сукоб између фикције и стварности. Фикције више нема! Остала је само стварност! Стварност ограђена невидљивим али свеприсутним кафезом кроз који не погледује с жудњом, већ с поштовањем сигурности коју јој пружа. И за њу је то, чини ми се, добро. Неће сањати сан који ће јој донети разочарање када се у њему пробуди. А шта ћемо са животом без фикције, можете ме такође питати? Вреди ли живот у којем волимо сопствени кафез? У којем не сањамо ван својих ограничења? Не бих умела ни Вама ни себи да одговорим на то питање. Не бих се дрзнула да говорим ни у име муслиманских ни у име наших жена. Недавно сам разговарала с мојом драгом пријатељицом, Вашом оданом читатељком такође, о томе како се њена и моја генерација жена снашла с пробуђеном свешћу. Доста трезвено је запазила, та моја драга пријатељица, да наше баке нису имале избора, да су попут Фатмине мајке, деловале 
спокојне у својим једнообразним улогама. Можда то и није било тако, али ретко која се међу њима усудила да покаже другачије. Довољно је било да буду жене и мајке. Нашим мајкама, приметила је та моја пријатељица, није било довољно да буду жене и мајке желеле су да буду и своје, да учине нешто од себе. У томе су многе и успеле. Омануле су, додуше, да у свему томе уживају и многе су због тога огорчене. Наша генерација, сматра моја пријатељица, хоће све - хоће да испуни и ужива у свакој од улога које јој живот нуди. Хоћемо ли у томе успети, писаће, надам се, наше унуке.

Неће Вас радовати ни да чујете да сам међу младим Арапима срела превелики број оних који сувише личе на Вашег Мурад-Џемала. Ти младићи, барем они из угледнијих и имућнијих породица, школовани по европски, попут Вашег Џемала, из ноћи у ноћ мастиком потапају расцеп између онога што се од њих очекује и онога што би они заправо желели. Породице су их слале у свет да га виде, упознају, искусе али су исто тако очекивале да се они помирљиво врате у живот породичних дужности. Ни они, као ни младе Арапкиње, заправо немају слободу избора. Иако су стасали на опојним изворима слободног живота, од њих се очекује да остатак живота проведу уз бунар дужности и обавеза. Неће они одабрати своју професију, она ће беспоговорно бити професија њихових очева. Нити ће одабрати своје жене, биће то оне које су за њих изабрали њихови родитељи. Речју, биће то живот који је за њих неко други унапред одредио. Можете ме питати, по чему се то заправо разликује од живота многих европских младића из богатих породица које су вековима у назад, па и данас, животе своје деце приносиле на олтар породичних дужности? Усудила бих се рећи да суштинске разлике у бити и нема. Једину разлику коју могу да увидим јесте то што је трагедија европских младића посве лична, а трагедија арапских и лична и друштвена. Док су европски младићи, поглавито, заточени у сопственим културама, они арапски, ти о којима Вам говорим, заточеници су двеју култура а да ниједној од њих у потпуности не припадају. Чујем Вас како ме опомињете да је Ваш Џемал био срећнији у Паризу него у Солуну. У том погледу, нисам срела превише Џемала међу младим Арапима данас - чини ми се да је премало оних који би уистину били срећнији тамо негде западније.
Превише сам Вам времена одузела сопственим мислима о Вашем роману, али морала сам с Вама да поделим запажања који су Вам, искрено се надам, посведочили до које мере су Ваше Нове савремене. Сигурна сам да ће Вас више занимати да чујете шта су други имали да кажу о њему. Радоваће Вас да знате да се књига у нашим ипак скученим издавачким околностима продаје добро. И још више да се чита. Неки од Ваших читалаца, оних који чине ширу читалачку јавност, писали су ми о својим утисцима о Новама. Бићу слободна да вам неке од тих утисака пренесем. „Поштована уреднице“, писао ми је извесни адвокат у пензији,

Као верни читалац издања Ваше издавачке куће, желим да Вама јавим да је роман Нове на мене оставио изванредан утисак. На њега ми је скренуо пажњу чланак који сам о Јелени Димитријевић прочитао у Политици. Како претходно ништа о њој и њеном делу нисам знао, пожурио сам да купим свој примерак књиге и уверим се да је заиста реч о занимљивом штиву. Морам Вам рећи и да жалим што је у канону српске књижевности тако тесно па се за Вашу ауторку није нашло истакнуто место. Радо бих читао још понешто од њених дела, уколико бисте их објавили!

Један други читалац, шездесетпетогодишњи доктор машинских наука који за себе каже да је сељак, написао ми је:

Хтео сам да Вам се похвалим да ме сажетак издања Нових, док сам га читао у Вашој књижари у Крагујевцу, навео да их одмах и купим. Баш ме заинтересовала њихова историјска тема, поготово што је о њој писала жена. Нисам знао за њу! А пише добро, занимљиво и пријемчиво за ширу читалачку публику. Штета што је нема међу ауторима у школској лектири. Ја сам то хтео да исправим, па сам један примерак купио својој кћерци. За њу је важно да се упозна с женским питањима о којима Јелена пише. Објавите још нешто њено историјске тематике, а да је занимљиво као Нове.

Међу писмима читалаца која су стигла на Гласникову адресу навела бих Вам још и одељак овог који је сачинио тридесетседмогодишњи неохелениста:

Обрадовао сам се када сам видео да сте објавили роман Нове. Током студија сам слушао понешто о Јелени Димитријевић и својевремено сам читао њена Писма из Солуна. Нове су ми биле посебно занимљиве због историјског тренутка 
о којем говоре, али не бих да занемарим ни социјални ни васпитни утицај који би оне могле да изврше само да се нађу у школској лектири. Као филолог, посебно ценим ауторкино познавање матерњег и страних језика. Чуо сам да је у неком од својих дела користила нишки дијалекат - то бих волео да читам!

Бићу слободна да с Вама поделим и делове писама које су ми упутили колеге и пријатељи, познаваоци а не само љубитељи књижевности. Чини ми се да су и њихови коментари о Новама драгоцени, јер унеколико одређеније говоре о данашњем значају Вашег романа од оних које су са нама поделили обични читаоци (под условом да данас ико верује у категорију обичног читаоца). Ево одељка писма колеге уредника, филозофа по образовању:

Већ сам ти се похвалио да сам Нове купио чим си их објавила, али мислим да ти нисам испричао како сам заправо сазнао ко је Јелена Димитријевић. Пре неколико година сам био у Нишу и видео сам да једна од улица носи Јеленино име. Питао сам нишке познанике ко је она била. Нико није умео да ми каже. По повратку у Београд сазнао сам да је била књижевница, да је стварала у првој половини 20. века, да је учествовала у Првом светском рату (sic!) као медицинска сестра. Узалуд сам тражио њена дела у књижарама све до твог издања Нових. А оне су ми откриле један „нови“ свет До њих нисам знао какав је у то време био однос између мушкараца и жена. Ауторка мије дочарала сву драмуженских личности у доба кад су жене биле предмет обожавања, али у поданичком односу, јер су их мушкарци у време турске империје доживљавали као власништво. Роман, нема сумње, нуди раскошну слику краја једне дуге епохе у којо су младе жене биле онемогућене да искажу богатство своје личности, у којој су се цениле њихове физичке одлике, а не духовне особине и квалитети. Права је штета што готово читав век нису штампана њена дела, осим пар изузетака. Ето још једног неправедно запостављеног српског писца! А њен јасан, сликовит, лиричан и префињен стил чине је једном од квалитетнијих српских списатељица прве половине 20. века. Нисам успео да нађем њене путописе, а волео бих да их прочитам. Јесу ли писани романтично, попут оних који су настали у доба кад се путовало дуго бродом или возом?

Обрадовала сам колегу вешћу да ће сада у књижарама моћи да нађе поновљено издање једног од Ваших путописа. А примерак наших
Нових путовао је дуго у Америку, на адресу моје драге пријатељице, теоретичарке књижевности. И ево шта је стигло као одговор, преко једног океана и ниједног мора:

\section{Драга моја,}

Хвала ти на поклону! Опрости што ми је требало толико времена да с тобом поделим своје мисли о књизи, иако сам је прочитала чим је стигла, и упркос позитивном и јаком утиску који је књига на мене имала и још увек има! Првенствено ме завео непосредни, танани и поетични стил који читаоца увлачи у свет романа и приближава јунацима приче на потпуно неодољив начин. Наративна река тече без сувишне патетике а опет емотивно набијена, тако да имам утисак да роман никога не може оставити равнодушним. Ретки су, чини ми се, наративни гласови, и у нашој и у светској књижевности, који у тој мери окупирају читаоца као Јеленин (N. B. непосредност и лакоћа приповедања учинили су да сам с Јеленом на ти и да би ми било чудно да морам да је ословим с Димитријевић). Када се томе придода чињеница да су ми период и живот описаних турских жена на прелазу у модерност били готово потпуно непознати (а апсолутно фасцинантни), добија се роман који се не испушта из руку. Јелена ми је отворила читав један нови свет за разумевање не само Турске тог периода, већ и нашег региона који је умногоме проживљавао динамику сличну оној описаној у Турској. Штавише, чини ми се да тај сукоб између традиционалног и модерног/прогресивног погледа на свет о којем је Јелена писала нажалост још увек одређује многе аспекте српског савременог друштва и доминантног политичког дискурса. Рекла бих да та паралела чини Нове још занимљивијим и важнијим делом за данашњег читаоца. Надам се да ћеш објављивањем овог романа успети да унеколико исправиш неправду и Јелену вратиш у видокруг српске књижевне критике и историје. Делим твоје мишљење да је крајње време да њено дело коначно дође до шире читалачке публике, јер отвара врата промишљању и расправи о турском наслеђу у оквиру српске културе и представља идеално чвориште из ког расправа може ићи и у правцу прошлости и у правцу будућности, нарочито поводом положаја жена и женског питања, у исламском свету, у Србији, као и у свету уопште.

Да су наше Нове подстакле размишљања о положају жена код оних који се претходно тиме нису бавили, сведочи писмо оне моје миле 
пријатељице чија сам Вам запажања о генерацијама наших бака, мајки и нас самих пренела с почетка овог писма. Новинарка по образовању, уредница у једној од медијских кућа по професији, та моја пријатељица писала ми је:

Опет си ме изненадила књигом наше ауторке која ми је била непозната! Излишно је да те питам где их налазиш када знам да их откриваш у нашој култури. Јесмо ли скоро помињале колико заправо не знамо шта се све у њој скрива? Подсети ме, молим те, да те следећи пут када се будемо виделе приупитам за мишљење о томе зашто смо у школама слушале само о Исидори Секулић, Мири Алечковић и Десанки Максимовић. Волела бих да сам Нове читала тада - можда бих се раније заинтересовала за питање судбине жена у психолошком и социјалном смислу. Овако сам морала да сачекам да окончам читање Јелениног романа па да осетим тупу тугу и освестим се о питањима о којима премало знам. Знаш да не марим превише за острашћене и нападно ангажоване проблематизације ма које ствари, па макар она била и женско питање. Утолико су ми Нове посебно годиле. Тако живописан роман, поучан и истовремено забаван за читање. Знам да ћеш ме поново укорити да свака идеја повремено захтева агресивнији приступ, да ћеш ме опоменути да се по ко зна који пут захвалим сифражеткињама на томе што су се избориле за право да се и мој глас важи, да ћеш ме терати да имам разумевања за оштру реторику феминисткиња, све знам... али ћу ти на то одговорити да ми се Јеленин начин ипак више допада. Рекла ми је све што је требало да ми каже а није ме заморила својим приступом и речима. Зар није тако боље? Далеко је више оних као што сам ја, него оних као што си ти, који ће више волети да им се горка пилула што морају да прогутају ипак умочи у мед. Заиста је фасцинантна та твоја Јелена! Сад ми је јасно због чега си ми толико причала о њој.

Било је и других писмених и усмених коментара на наше Нове, али Вас нећу више оптерећивати наводећи их понаособ. Уместо тога, дозволићу себи да их сумирам. Ко год је ишта чуо о Вама и Новама пожелео је да их прочита, а ко их је прочитао тај жели и даље да Вас чита! Вашу читалачку публику, посве очекивано за наше прилике, поглавито чине припадници средње и старије високообразоване генерације. (Мада ћете волети да чујете да и деца уживају у Вашим Новама! Да само знате колико су њихова промишљања о Вашем роману драгоцена!) И та генерација о којој Вам сада пишем, у складу с вредностима заједнице коју чини, историчност Вашег романа налази изузетно занимљивом. Ваш роман јој говори много тога што њени припадници претходно нису знали о узбудљивом историјском тренутку и још више о геополитичком простору о којем пишете. Многи су имали утисак, као што сте и сами могли да увидите из скромног узорка читалачких одговора на Ваш роман које сам Вам овом приликом пренела, да им говорите и о Србији, и онда и сада, док им приповедате о Солуну у оквиру турског царства. Но, занимљива историјска позадина романа није омела ваше читаоце, како сте могли да се уверите, да занемаре тако важну женску и личну историју нова. Некима је она била посве нова, а некима добро позната али одвећ ново предочена. Нема оних које Ваше приповедачко и стилско умеће није оставило без даха! Знам и оне, мада их је тешко приволети да то јавно и признају, који су наше Нове склопили са сузама у очима. Увек сам се питала да ли писци цене читаоце који их читају и умом и срцем онолико колико, посве отворено признајем, ценим писце који своја дела пишу у савршеној сразмери разума и осећања? Уколико сте ви једна од њих, а бићу слободна да Вас у њих убројим, онда Вам могу рећи да сте Ваше обожаваоце и поштоватеље нашли и у новој генерацији читалаца! Сви који Вас читају неизмерно Вас воле и цене! Можете ли пожелети нешто више, у том погледу барем?

Остављам Вас сада у нади да сам оправдала Ваша очекивања и поверење које сте ми тако несебично указали пре четири године када су се наше Нове отиснуле из Сопствене собе у свет! Напуштам Вас, за сада, и у знању да ће још много тога бити учињено да и друга Ваша дела дођу до нових читалаца која ће, исто тако сасвим поуздано знам, беспоговорно освојити као и оне којима смо подарили наше Нове.

\section{Одано Ваша,}

Уредница 
Nataša Marković

Službeni Glasnik Publishing House

Jelena Dimitrijević in a Room of One's Own:

The Conquest of the New Generation of Readers

One hundred years after its first edition, the new edition of Jelena Dimitrijevic's novel Nove was published by Službeni glasnik in the book collection A Room of One's Own - a collection dedicated to literary works written by Serbian and foreign women writers. After the reprints of Jelena Dimitrijević's books Pisma iz Niša: o haremima (Letters from Niš: About Harems), published by Narodna biblioteka Srbije and Dečije novine in 1986; and by Prosveta, Niš, in 2003, and her book Pisma iz Soluna (Letters from Salonika), published by Karpos in 2008, a new edition of her once famous novel was to be the third step towards reintroducing one of Serbia's most important woman writers into the Serbian publishing and reading scene. Four years after the publication of Glasnik's edition of Nove, it is possible to discuss the new generation of Jelena Dimitrijević's readers. In this article, written in the form of the letter, the editor of the new edition of Nove informs its author about her entry into Glasnik's Room of One's Own, the outcome of her new appearance before the readership, and who, how and why reads Nove today. Composed in the spirit of performative criticism and reception theory, this letter sums up the importance Jelena Dimitrijević's novel has today, more than one hundred years after it was first published.

Keywords: Jelena Dimitrijevic, Nove, letter, readers, performative criticism, reception theory

\section{Јасмина Мипановић}

Институт за савремену историју

Београд

821.163 .41 .09 димитријевић

$061.2-055.2(4.2000$

https://doi.org/10.18485/jdimitrijevic.2018.ch6

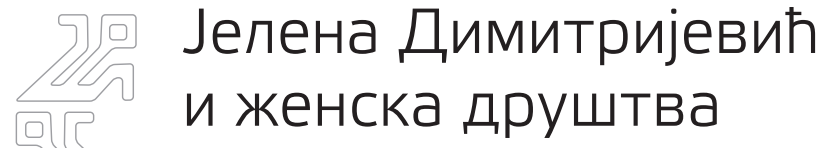

Јелена Димитријевић је више позната по својој књижевној делатности него по свом друштвеном, патриотском и хуманитарном раду. Била је чланица три женска друштва у којима је активно радила Тај део живота Јелене Димитријевић до сада није био довољно познат и представљао је прави изазов за истраживање. Показало се, на крају, да је редовна чланица Нишке подружине Женског друштва постала 1881, а од 1898. била је и члан Литерарног одбора часописа Домаћица. До сада није било познато да је Јелена 1903. године била и чланица друштва Одбора госпођа „Кнегиња Љубица“ о чему су пронађени подаци. Нешто је боље позната њена делатност у оквиру Кола српских сестара, а нарочито њена сарадња у календару Вардар. У овом периоду упознала је и започела дугогодишње пријатељство са Делфом Иванић, са којом ће сарађивати и у Народном женском савезу. Све ово указује и да је Јелена Димитријевић била посвећена, осим књижевном стваралаштву, заштити слабијих, пре свих жена, деце, али је подржавала и борбу за национално ослобођење српског народа на територији Османског царства и Хабзбуршке монархије.

кључне речи: Јелена Димитријевић, Женско друштво, Одбор госпођа „Кнегиња Љубица“, Љубица Луковић, Коло српских сестара, Делфа Иванић, књижевница 